\title{
Valorization of the Mucilage Juice of Cocoa Beans for the Production of a Biopesticide based on Bacillus thuringiensis var.kurstaki HD-1
}

\section{ACHI Stanislas Maurice Akpo,4*, YAPO Atse Alain ${ }^{1,4}$, DJENI N' dede Théodore², GADJI Alahou André Gabaze ${ }^{1,6}$, COULIBALY Kalpy Julien ${ }^{4}$, GNEPE Jean Robert ${ }^{5}$, YAPO Ossey Bernard ${ }^{1,3}$ and TYAGI Dayal Rajeshwar ${ }^{5}$}

${ }^{1}$ Laboratory of Environmental Sciences (LSE), Training and Research Unit in Environmental Sciences and Management (UFR-SGE), Nangui Abrogoua University 02 BP 801 Abidjan 02, Côte d'Ivoire

${ }^{2}$ Biotechnology and Food Microbiology Laboratory, Department of Food Science and Technology, University of Nangui Abrogoua, Abidjan, 02 BP 801, Côte d'Ivoire

${ }^{3}$ Central Laboratory for the Environment of the Ivorian Antipollution Center (LCE-CIAPOL) 20 BP 650 Abidjan 20, Côte d'Ivoire

${ }^{4}$ Environment and Health Laboratory, Environmental Microbiological and

Control Unit of the Pasteur Institute of Côte d'Ivoire 01 BP 490 Abidjan 01

${ }^{5}$ Laboratory for Bioconversion of Wastewater and Sewage Sludge into High Added Value

Products, National Institute for Scientific Research (INRS-Water Earth and Environment),

University of Quebec, Quebec, Canada

${ }^{6}$ Technology Laboratory of the National Agronomic Research Center (CNRA), 01 BP 1740 Abidjan 01Côte d'Ivoire

*Corresponding author

\section{A B S T R A C T}

\section{Keywords}

Mucilage juice, Cane molasses, biopesticide, Bacillus thuringiensis var. kurstaki HD-1, liquid fermentation

Article Info

Accepted: 24 October 2020 Available Online: 10 November 2020
The use of microbial pesticides in agriculture has someadvantages, but their production ina non-conventional experimental tests constituate a challenge. This study purpose is to evaluate the potential of cocoa mucilage juice. The mucilage juice of cocoais a substratum, that has been used as an alternative growing test and associated to bacteria such as Bacillus thuringiensis var. kurstaki HD-1 (Btk HD-1) for the production of a biopesticide. After determining the physico-chemical characteristics of the mucilage juice, different combinations has been made with 2\% (M2\%), 4\% (M4\%), 6\% (M6\%) and 7\% (M7\%) cane molasses were established, then inoculated with $2 \%$ of the inocula and incubated at $30{ }^{\circ} \mathrm{C}$ for 48 hours under agitation. The results showed that the substratum contained nitrogen $(1.68 \mathrm{~g} / \mathrm{L})$ and carbon $(9.9 \mathrm{~g} / \mathrm{L})$, which has an important mineral such as potassium $(87.3 \mathrm{mg} / \mathrm{L})$, phosphorus $(38 \mathrm{mg} / \mathrm{L})$ and magnesium $(25.42 \mathrm{mg} / \mathrm{L})$. The growth of Btk HD-1 in cocoa mucilage juice with $2 \%$ molasses (M2\%) was the highest (p $<0.0001$ ) with average concentration of $1.6 \times 10^{9} \mathrm{CFU} / \mathrm{mL}$ for cells and $2.3 \times 10^{9} \mathrm{CFU} / \mathrm{mL}$ for spores. This combination therefore offers good prospects for the production of the Btk HD-1 biopesticide. 


\section{Introduction}

The emergence of pests that are resistant to certain chemical pesticides reduces the effectiveness and sustainability of chemical control. World wide, particularly in Côte d'Ivoire, these pests are the cause of a significant reduction in agricultural production, resulting in economic losses. However, since independence, Côte d'Ivoire economy has been lean back on agriculture. For decades, chemical control has been used to ensure the phytosanitary protection of plants and thus increase agricultural yields. Moreover, chemical pesticides are suspected of having considerable harmful side effects on crops, human health and the environment. Of this fact, the use of biopesticides in agriculture is strongly recommended. There are several types of biopesticides, but those based on Btk HD-1 are the subject of this study. These biological pesticides have several advantages. They are biodegradable and have very low toxicity on living organisms and the environment (Silverio et al., 2009). Also, they have a broad spectrum of action on several pests (Mondédji et al., 2015).

Biopesticides based on Btk HD-1 are usually some suspensions formulated from mixtures of spores and protein crystals synthesized by the bacteria after cultivation (Adjallé, 2009). Its insecticidal activity resides in the production of a parasporal protein crystal called delta-endotoxin which is formed during sporulation (Osman et al., 2015). Btk HD-1 grows in a medium which is important in carbon, nitrogen and mineral salts (Valicente et al., 2008). However, the use of bioinsecticides remains very limited due to the relatively high production costs and the low stability of the product in the time (Mounsef et al., 2014). Indeed, several authors have purposed different by-products agricultural and agro-industrial that are important in carbon and nitrogen such as soybean meal, maize starch, yeast extract, peanut flour, fish meal, sugar cane molasses, hydrolyzed sludge and waste water treatment sludge that have been successfully substituted for expensive media (Satinder et al., 2007; Valicente et al., 2010; Zhuang et al., 2011) and including kitchen waste (Zhang, et al., 2013). Côte d'Ivoire is an agricultural country and with the advent of new technologies aimed at the valorisation of bulky residues from industrial, agricultural or domestic activities (Gadji, 2017). It is opportune that the research on crop protection to explore the use of certain local products that are not exploited for the production of low cost bioprotection agents. According to studies by Anvoh (2013), cocoa mucilage juice is one of the most important by-products of cocoa abandoned on farms by farmers each year with a volume of more than 300,000,000 L.

The objective of this work is to evaluate the nutrient potential of cocoa mucilage juice, a local substratum, as an alternative growing medium for the production of biopesticide based on Btk HD-1. This approach will add value to cocoa cultivation and increase the income of the farmer.

\section{Materials and Methods}

\section{Bacillus thuringiensis var. kurstaki HD-1}

The bacterium, Bacillus thuringiensis var. kurstaki HD-1 (Btk HD-1), was isolated from the fermented broth of wastewater from starch industries. This fermented broth is obtained by bioreaction of this waste water and packaged in plastic bottles at the Laboratory of Bioconversion of Waste water and Sewage Sludge into High Value Added Products, of the National Institute for Scientific Research (INRS Eau-Terre-Environment), University of Quebec, Canada. The strain in the form of broth was provided under ATCC number 
33679 by the Canadian Forest Service (CFS) Laboratory in Sainte-Foy (Quebec, Canada).

\section{Collect and physico-chemical characterisation of the Mucilage Juice from Cocoa Beans (JMFC)}

An empty $50 \mathrm{~kg}$ filtisac branded nylon bag placed on pieces of wood was used to collect the beans surrounded by their white solid mucilage. After liquefaction the solid mucilage into liquid matter, the juice has been collected in a basin of capacity $10 \mathrm{~L}$ placed under the bag. It was transferred to a cooler of capacity $2.5 \mathrm{~L}$ hermetically sealed and then the sample obtained was placed in a big cooler $(5 \mathrm{~L})$ in which there was some ice. The sample has been transported to the Central Environmental Laboratory (LCE) of the Ivorian Anti-Pollution Centre (CIAPOL). It has been filtered with cotton wool to remove the suspension materials, pod debris and spine.

The physicochemical parameters of the mucilage juice were measured according to different methods recapitulate in Table 1 before their utilization as culture medium. The minerals were determined by atomic absorption spectrometry, using the slightly modified method described by Toundou (2016).Indeed, $10 \mathrm{~mL}$ of cocoa mucilage juice was mixed with $6 \mathrm{~mL}$ of a solution of chloridric acid $(2 \mathrm{~N} \mathrm{HCl})$ and $3 \mathrm{~mL}$ of sulphuric acid. The mixture was heated for 2 hours at $150^{\circ} \mathrm{C}$. The solution (mineralise) obtained was then filtered and the concentrations of the minerals $(\mathrm{Cu}, \mathrm{Fe}, \mathrm{Zn}, \mathrm{Pt}$, $\mathrm{Mg}, \mathrm{Na}, \mathrm{K}, \mathrm{Mn}, \mathrm{Ca}$ ) were quantified.

\section{Biopesticide production based on Btk HD-1}

\section{Preparation of culture media}

The media for the production of Btk HD-1 have been conceived in the laboratory according to the following principle: The mucilage juice was divided into different batches of $50 \mathrm{~mL}$ which were supplemented with different proportions particularly 2, 4, 6 and $7 \%$ of cane molasses (M) as an additional source of carbon, to constitute the media M2\%: $50 \mathrm{~mL}$ JMFC + 2\% M, M4\%: $50 \mathrm{~mL}$ $\mathrm{JMFC}+4 \% \mathrm{M}, \mathrm{M} 6 \%: 50 \mathrm{~mL} \mathrm{JMFC}+6 \% \mathrm{M}$, M7\%: $50 \mathrm{~mL}$ JMFC $+7 \%$ M respectively. The mucilage juice (JMFC) without the addition of molasses was used as a control.

\section{Preparation of inocula and fermentation process}

The isolation of Btk HD-1 colonies was realized by streak seeding technique on trypticase soy agar (TSA) after 12 hours of culture at $30^{\circ} \mathrm{C}$ in $9 \mathrm{~mL}$ of trypticase soy broth from $1 \mathrm{~mL}$ of fermented starch industry waste water. The inocula were then prepared from isolated colonies of Btk HD-1 using the slightly modified technique of Mourin et al., (2015). Indeed, four $250 \mathrm{~mL}$ glass bottles containing $50 \mathrm{~mL}$ JMFC each were supplemented with 2, 4, 6 and $7 \%$ of cane molasses. The different media (Control, $\mathrm{M} 2 \%, \mathrm{M} 4 \%, \mathrm{M} 6 \%$ and $\mathrm{M} 7 \%$ ) were adjusted to $\mathrm{pH} 7.2$ with sodium hydroxide and chloridric acid $(\mathrm{NaOH}, 1 \mathrm{~N} / \mathrm{HCl} 2 \mathrm{~N})$, sterilised at $121{ }^{\circ} \mathrm{C}$ for $15 \mathrm{~min}$. They were each inoculated with an isolated colony of strain Btk HD-1. The preparations obtained were homogenized by vortexing and cultured in a shaker incubator (Biobase, China) at 250 $\mathrm{rpm}$ and $30^{\circ} \mathrm{C}$ during 12 hours. The mucilage juice without cane molasses, treated under the same conditions, served as a control.

The fermentation process was carried out according to the method of Valicente et al., (2010). Indeed, five glass bottles of $250 \mathrm{~mL}$ capacity were prepared as previously. They were inoculated with $1 \mathrm{~mL}(2 \% \mathrm{v} / \mathrm{v})$ of each of the media inocula. They were incubated at $30^{\circ} \mathrm{Cin}$ orbital shaker (shaking incubator) at 
$250 \mathrm{rpm}$ during 48 hours. Aliquots were collected regularly every 3 hours for the first 24 hours and every 6 hours until the end of the experiment to count viable cells and spores.

\section{Enumeration of viable cells and spores}

The evaluation of the cells (vegetative form) and viable spores was done in accordance with the technique of direct seeding on agar medium carried out by Gadji et al., (2016). This technique consisted of spreading $0.1 \mathrm{~mL}$ of the aliquots taken from the dilutions on trypticase soy agar (TSA) medium in a Petri dish. Then, the Petri dishes were incubated an oven at $30^{\circ} \mathrm{C}$ for 24 hours. After incubation, only results between 30 and 300 colonies were used to estimate the total number of viable cells in colony forming unit per millilitre $(\mathrm{CFU} / \mathrm{mL})$.

For the enumeration of viable spores, the dilutions were first heated in a water bath at $80^{\circ} \mathrm{C}$ for $15 \mathrm{~min}$. An aliquot of $0.1 \mathrm{~mL}$ of these dilutions was spread on solid TSA medium in petri dishes. Each dilution was spread in triplicate. The petri dishes were then incubated at $30^{\circ} \mathrm{C}$. Enumeration was realized after 24 hours incubation in the oven and resultsbetween 30 and 300 colonies were retained and expressed as CFU/mL (Zhang et al., 2013).

\section{Determination of $\mathbf{p H}$}

The $\mathrm{pH}$ of each culture media, adjusted before sterilisation to 7.2 with $1 \mathrm{~N} \mathrm{NaOH} / \mathrm{HCl} 2 \mathrm{~N}$ was determined and adjusted until the end of fermentation (48 hours) in the different media according to Valicente et al., (2010). Each pH was determined in three repetitions for each medium and at different times.

\section{Statistical analysis of the data}

The variability of cell and spore concentrations in each culture medium was studied by an analysis of variance using the ANOVA method of Xlstat version 2016 software. Comparisons of the cell and spore averages of the five culture media (control, $\mathrm{M} 2 \%, \mathrm{M} 4 \%, \mathrm{M} 6 \%$ and $\mathrm{M} 7 \%$ ) were realized by Tukey test with level significance $95 \%$.

\section{Results and Discussion}

Physico-chemical characteristics of the mucilage juice of cocoa beans

Table 2 presents the physico-chemical characteristics, in particular the concentrations of total organic carbon $(\mathrm{Ct})$, total nitrogen $(\mathrm{Nt})$ and the $\mathrm{C} / \mathrm{N}$ ratio of the cocoa bean mucilage juice (JMFC). Indeed, this juice contains $9.90 \mathrm{~g} / \mathrm{L}$ of $\mathrm{Ct}$ and $1.68 \mathrm{~g} / \mathrm{L}$ of Nt. His $\mathrm{pH}$ before fermentation is 3.4 and $\mathrm{C} / \mathrm{N}$ ratio is 5.89 . This juice also contains high levels of potassium $(87.3 \mathrm{mg} / \mathrm{L})$, total phosphorus (38.00 $\mathrm{mg} / \mathrm{L})$ and magnesium (25.42 mg/L). Sodium, calcium, iron, copper and zinc contents are 15.21, 5.47, 3.31, 0.80, $0.29 \mathrm{mg} / \mathrm{L}$ and manganese contents are less than $0.02 \mathrm{mg} / \mathrm{L}$ (Table 3).

\section{pH evolution during the production of Btk HD-1}

Fig. 1 shows the $\mathrm{pH}$ changes during the production of Btk HD-1 in mucilage juice supplemented with cane molasses. The results showed a variation of $\mathrm{pH}$ in the different media after 48 hours of fermentation. A decrease of $\mathrm{pH}$ was observed in all media during the first 6 hours of fermentation with decreases of $0.75,1.16,1.24,0.95,1.08$ respectively. After this period, and until the end of the process, a progressive evolution of $\mathrm{pH}$ was observed in the $\mathrm{M} 2 \%$ and $\mathrm{M} 4 \%$ culture media to reach 8.47 and 8.07 respectively and a $\mathrm{pH}$ decrease in the $\mathrm{M} 6 \%$ and $\mathrm{M} 7 \%$ media (6.3 and 6.2 respectively); the $\mathrm{pH}$ in the control stayed constant and near of the neutrality. The Tukey test at the 5\% level shows a significant difference with $\mathrm{p}<$ 
0.001 between the control, M2\%, M4\% and the $\mathrm{M} 6 \%$ and $\mathrm{M} 7 \%$ media.

\section{Production of BtkHD-1 cells in different media during fermentation}

In this study, different cell growth profiles were observed in the different media tested, the results showed a variation of cells during the 48 hours of fermentation (Fig. 2). During fermentation, cell production by the Btk HDlincreasein the different media (Control, $\mathrm{M} 2 \%, \mathrm{M} 4 \%, \mathrm{M} 6 \%$ and $\mathrm{M} 7 \%$ ) between 0 and 3 hours. The respective average were $3.4 \pm$ $0.056 .10^{6} \mathrm{CFU} / \mathrm{mL}$ for the control, $3.3 \pm$ $0.054 .10^{6} \mathrm{CFU} / \mathrm{mL}$ for $\mathrm{M} 2 \%, 4.2 \pm 0.068 .10^{6}$ $\mathrm{CFU} / \mathrm{mL}$ for $\mathrm{M} 4 \%$ and $3.2 \pm 0.05 .10^{6} \mathrm{CFU} / \mathrm{m}$ for $\mathrm{M} 6 \%$ at 3 hours of fermentation. After this period, cell production by the Btk HD-1 seemed to be stable in the five media until 18 hours of fermentation, at this time themediumM $2 \%$ has reached a maximum production with a respective average of $1.7 \pm$ 0.03.10 ${ }^{8} \mathrm{CFU} / \mathrm{mL}$. After 18 hours, the cell production of Btk HD-1 in the M2\% medium increased slightly compared to the other four media (Control, M4\%, M6\%, M7\%), which decreases until the end of the fermentation process. Moreover, the media with lower cell production were $\mathrm{M} 6 \%$ and $\mathrm{M} 7 \%$. The respective average were $1.6 \pm 0.026 .10^{9}$ $\mathrm{CFU} / \mathrm{mL}$ for $\mathrm{M} 2 \%$ compared to $9 \pm 0.15 .10^{6}$ $\mathrm{CFU} / \mathrm{mL}$ for the control, 3.3.107 $\pm 0.05 .10^{7}$ $\mathrm{CFU} / \mathrm{mL}$ for $\mathrm{M} 4 \%, 2.2 \pm 0.04 .10^{5} \mathrm{CFU} / \mathrm{mL}$ for $\mathrm{M} 6 \%$ and $2 \pm 0.03 .10^{5} \mathrm{CFU} / \mathrm{mL}$ for $\mathrm{M} 7 \%$.
The statistical analysis of the data by a Tukey test at the 0.95 level showed a significant difference with $\mathrm{P}<0.0001$ for cell production by Btk HD-1 in the different media tested.

\section{Production of viable spores of Btk HD-1 in the different media during fermentation}

The results showed a variation of spores in the five media during the 48 hours of fermentation (Fig. 3). Spore production in the different media did not start at the same time. It started at 9 hours of fermentation for the control, 12 hours for the media (M2\%, M4\%) and finally 15 hours for the media (M6\% and $\mathrm{M} 7 \%$ ). The respective average were $2.1 \pm$ $0.035 .10^{6} \mathrm{UFC} / \mathrm{mL}$ for the control, $2.3 \pm$ $0.038 .10^{6} \mathrm{UFC} / \mathrm{mL}$ for $\mathrm{M} 2 \%, 2.4 \pm 0.04 .10^{6}$ $\mathrm{UFC} / \mathrm{mL}$ for $\mathrm{M} 4 \%, 2.7 \pm 0.044 .10^{5} \mathrm{UFC} / \mathrm{mL}$ for $\mathrm{M} 6 \%$ and $2 \pm 0.031 .10^{5} \mathrm{UFC} / \mathrm{mL}$ for $\mathrm{M} 7 \%$. After these periods, spore production by Btk HD-1 in the media (Control, M2\%, $\mathrm{M} 4 \%, \mathrm{M} 6 \%, \mathrm{M} 7 \%$ ) was similar until 30 hours of fermentation. After this period, only the M2\% medium show high spore production until the end of the experiment (48 hours), with an average $2.3 \pm 0.037 .10^{9}$ $\mathrm{CFU} / \mathrm{mL}$. At the same moment, the spores production was decrease in the media (Control, M4\%, M6\%, M7\%).The statistical analysis of the data by Tukey test with level significance $0.95(\mathrm{P}<0.0001)$ showed a significant difference in spore production by Btk HD-1 in the different media tested.

Table.1 Methods for the analysis of the physico-chemical parameters of the mucilage juice of the Cocoa beans (Toundou, 2016; Gadji et al., 2016)

\begin{tabular}{|c|c|c|}
\hline Parameters & Methods & References \\
\hline pH & Electrometric method & CEAEQ (2003) \\
\hline Total organic carbon $(\mathrm{Ct})$ & Walkley-Black method & Martinez-Chois (2012) \\
\hline Total nitrogen $(\mathbf{N t})$ & Colorimetric method & CEAEQ (2014) \\
\hline $\begin{array}{l}\mathrm{Cu}, \mathrm{Fe}, \mathrm{Zn}, \mathrm{Pt}, \mathrm{Mg}, \mathrm{Mn}, \mathrm{Na}, \mathrm{K}, \\
\mathrm{Ca}\end{array}$ & $\begin{array}{l}\text { Dosing by spectrometry } \\
\text { atomic absorption }\end{array}$ & Toundou (2016) \\
\hline
\end{tabular}


Table.2 Physico-chemical characteristics of the mucilage juice of cocoa beans

\begin{tabular}{|l|l|}
\hline Parameters & Values \\
\hline pH & 3,4 \\
\hline Total organic carbon $(\mathrm{g} / \mathrm{L})$ & 9.90 \\
\hline Total nitrogen $(\mathbf{g} / \mathrm{L})$ & 1,68 \\
\hline C/N ratio & 5,89 \\
\hline
\end{tabular}

Table.3 Content in minerals ( $\mathrm{mg} / \mathrm{L}$ ) of the mucilage juice of cocoa beans

\begin{tabular}{|l|c|}
\hline Parameters & Teneur $(\mathbf{m g} / \mathbf{L})$ \\
\hline Copper $(\mathbf{C u})$ & 0,80 \\
\hline Iron $(\mathbf{F e})$ & 3,31 \\
\hline Zinc $(\mathbf{Z n})$ & 0,29 \\
\hline Total phosphorus (Pt) & 38,00 \\
\hline Magnesium (Mg) & 25,42 \\
\hline Sodium (Na) & 15,21 \\
\hline Potassium (K) & 87,30 \\
\hline Manganese (Mn) & $<0,02$ \\
\hline Calcium (Ca) & 5,47 \\
\hline
\end{tabular}

Fig.1 pH variation during fermentation of Btk HD-1

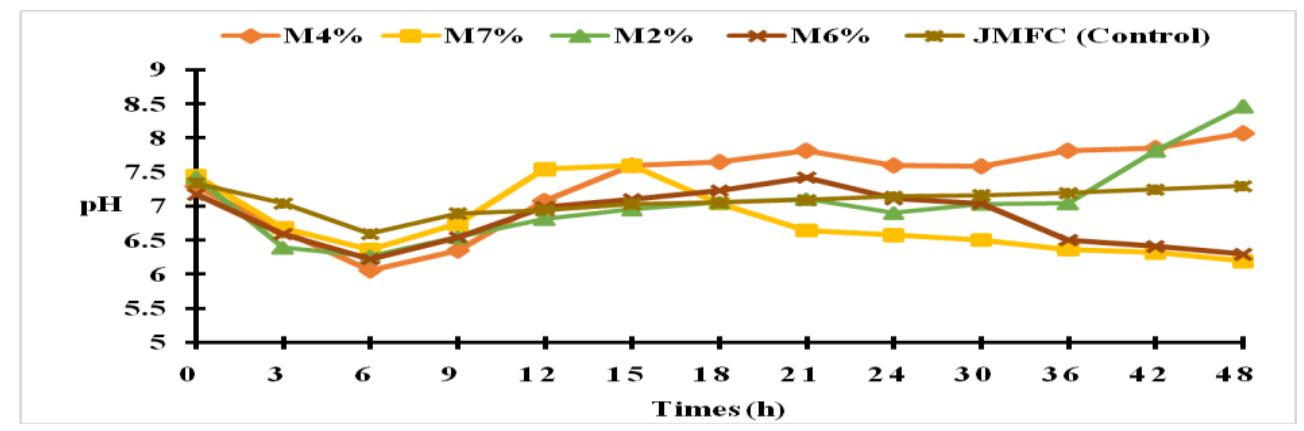

JMFC (50 mL): Control, M2\%: JMFC + 2\%M, M4\%: JMFC + 4\%M, M6\%: JMFC + 6\%M, M7\%: $\mathrm{JMFC}+7 \% \mathrm{M}$

Fig.2 Growth evolution profiles of Btk HD-1 cells during fermentation in media

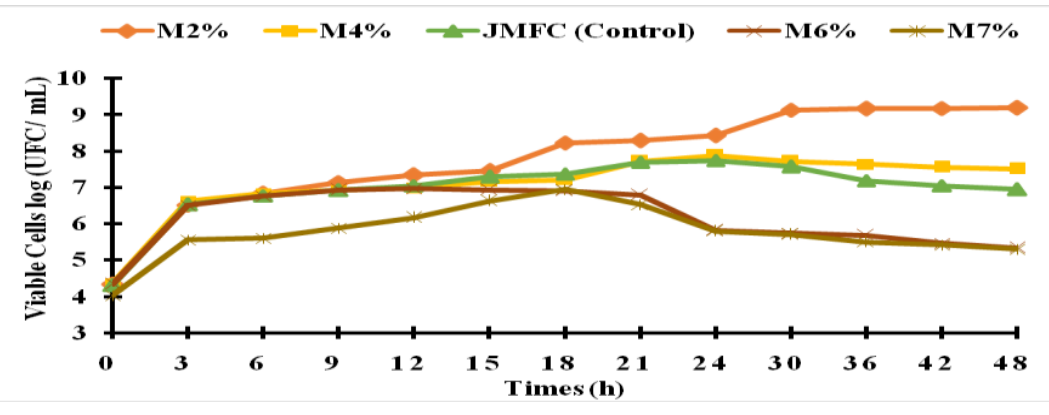


Fig.3 Growth evolution profiles of Btk HD-1 spore during fermentation in media

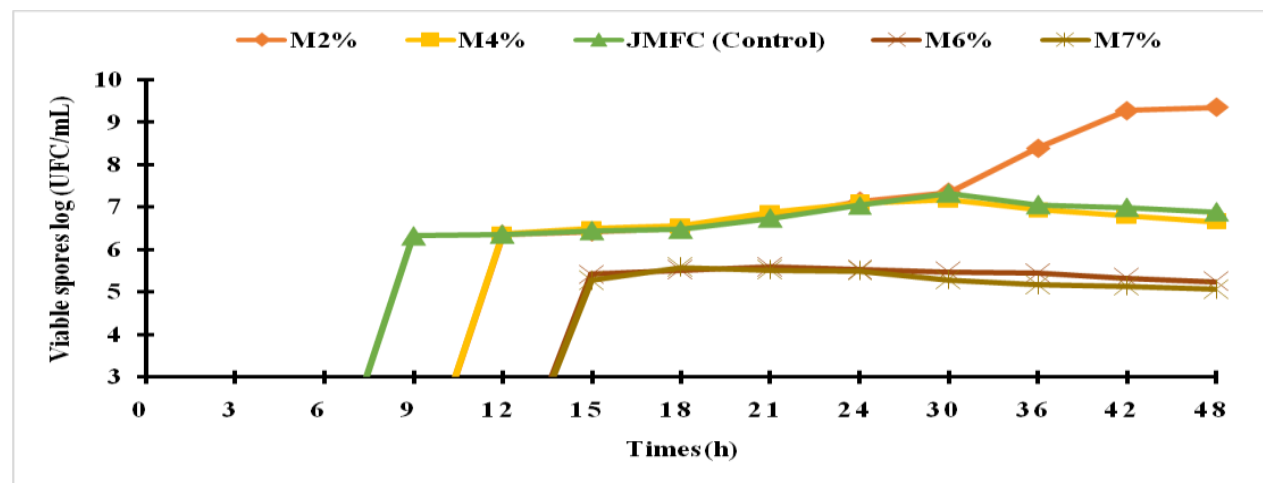

Physico-chemical characteristics of the mucilage juice of cocoa beans

The mucilage juice of cocoa beans contains elements that can be used as a substratum for the culture of the Btk HD-1 bacteria. These elements are nitrogen, carbon and minerals $(\mathrm{Mg}, \mathrm{Na}, \mathrm{Fe}, \mathrm{Ca}, \mathrm{K}, \mathrm{P}$ ) which are important for growth and sporulation of this bacteria, as indicated by Gadji et al., (2016). The results obtained in the present study are different from those of Anvoh (2013).Indeed, the concentrations of potassium $(87.3 \mathrm{mg} / \mathrm{L})$, total phosphorus (38 $\mathrm{mg} / \mathrm{L})$, magnesium $(25.42$ $\mathrm{mg} / \mathrm{L})$ obtained in the cocoa mucilage juice tested in this study are much lower than those obtained by this author who found some concentrations of $950 \mathrm{mg} / \mathrm{L}$ for potassium, $62.47 \mathrm{mg} / \mathrm{L}$ for total phosphorus and $82 \mathrm{mg} / \mathrm{L}$ for magnesium. The differences in concentrations would certainly be due to the use of agricultural inputs, soil type, the cocoa clones present and the region of origin of the cocoa samples. This was also reported by Gadji et al., (2016) in their study on cocoa pericarp. In addition, the carbon-nitrogen ratio $(\mathrm{C} / \mathrm{N})$ plays an important role in growth, sporulation and protein (delta-endotoxin) production by Btk HD-1(Stephanie et al., 2014).The value obtained in this study is similar to the value (5.74) of Vidyarthi et al., (2002)in unenriched sewage sludge.
However, this value is extensively below of those reported by several other authors in different sources, particularly 10 in soy flour (Stephanie et al., 2014), 12.87 from waste water from starch industries $(\mathrm{Vu}$ et al., 2009)and finally, 56.90 in cocoa pericarps (Gadji et al., 2016).

\section{pH evolution during the production of Btk HD-1}

The $\mathrm{pH}$ evolution profiles studied in the different media showed a variation, she would due to the consumption of the mucilage juice from the cocoa beans and to changes in metabolic activity. Indeed, the decrease in $\mathrm{pH}$ observed in the media from their initial $\mathrm{pH}$ of around 7 to 6 during the first 6 hours could be explained by the use of carbohydrates by the Btk HD-1 bacteria causing an acidification of the culture media (Barje et al., 2012; El fels et al., 2014). The values obtained during our work were similar in terms of the $\mathrm{pH}$ decrease at the beginning of the fermentation process in the different media to those of Valicente $e t$ al., (2008), in the context of their work on the evaluation of carbon and nitrogen-rich media for biopesticide production. Also, they were similar to those of Zhang et al., (2013) in their study on kitchen waste as a fermentation substrate and finally to those of SalazarMagallon et al., (2015)in their study on the 
use of industrial by-products for the production of Btk HD-1. These authors observed a drop in $\mathrm{pH}$ ranging from 7 to 6 during the first 10 hours of fermentation. After this period, and until the end of the process, the progressive increase in $\mathrm{pH}$ in the $\mathrm{M} 2 \%$ and $\mathrm{M} 4 \%$ culture media would due to a bacteria hydrolysis of nitrogen with production of ammonia associated with the degradation of proteins and the decomposition of organic acids. The values obtained were similar to those of Montiel et al., (2001) and Vidyarthi et al., (2002). These authors found $\mathrm{pH} 8$ and 8.5at the end of fermentation in the case of using sewage sludge for the growth of Btk HD-1. The $\mathrm{pH}$ stabilization observed until the end of fermentation in the control could be explained by an equilibrium between the sources of carbon and nitrogen in this medium. This result (7) is similar with that of Valicente et al., (2008)in the different media (1.0\% corn juice $+3.0 \%$ soybean powder and Luria Bertani + salts).

\section{Production of BtkHD-1 cells in different media during fermentation}

The high cell production during the first hours of fermentation ( 0 and 3 hours) is below that of Gazali et al., (2019) in their study of cell production by $\mathrm{Bt}$ berliner in natural media. These authors obtained average included between $5.9 .10^{11}$ to $9.8 .10^{11}$ cell $/ \mathrm{mL}$ for the media tested. This difference in value would probably be related to the Bt strain used and the composition of the culture media. Indeed, the rapid production of cells after 3 hours of fermentation in both cases demonstrates the influence of the composition of the medium on cell production. This constat was also reported by Gazali et al., (2019). The exponential cell growth time in this study was shorter than that of Ndao et al., (2019) using industrial wastewater. These authors obtained an exponential growth that lasted 4 times longer than ours. The stability of cell production observed after this period until 18 hours of fermentation would certainly be due to a decrease in nutrients in the culture media. At this time, the peak observed in the M2\% medium would be due to a medium that is still more favourable to the growth of Btk HD-1 than the others. After this period, the decrease in cell production observed until the end of the experiment in almost all media would be strongly due to a total poverty of nutriments in the media or to cell lysis. Moreover, the results obtained at the end of fermentation in the media (Control, M4\%, M6\%, M7\%) were lower than those of Vidyarthi et al., (2002)in terms of the number of viable cells. These authors obtained $8.10^{8}, 6.2 .10^{8}, \quad 5.8 .10^{8}$ $\mathrm{UFC} / \mathrm{mL}$ in three different media (Soy yeast extract, soybean meal, waste water sludge).

\section{Production of viable spores of Btk HD-1 in the different media during fermentation}

Concerning the production of spores, it did not all start at the same time in the media. In the control it began during the first hours of fermentation $(9 \mathrm{~h})$ compared to the M2\%, M4\% and M6\%, M7\% (12 and $15 \mathrm{~h}$ ) media. This difference would be due to a more rapid consumption of the bacteria (Btk HD-1) from carbon $(\mathrm{C})$ and nitrogen $(\mathrm{N})$ sources present in small quantities. This constat was also reported by Barnabé (2004) in his study of the use of sewage sludge as medium of fermentation. Spore production is stable in the media from 9 hours to 30 hours of fermentation. It could be due to a poverty of the media in nutriments. After 30 hours of fermentation, the $\mathrm{M} 2 \%$ medium was the most favourable for spore production by Btk HD-1. This indicates that the sporulation process worked more efficiently in this medium than in the others. The result obtained for $\mathrm{M} 2 \%$ $\left(2.3 \pm 0,037.10^{9} \mathrm{CFU} / \mathrm{mL}\right)$ was high compared to Yezza et al., (2005) and Mourin et al., (2015). The first authors obtained 5.4.10 ${ }^{8}$ and $7.9 .10^{8} \mathrm{CFU} / \mathrm{mL}$ in the untreated 
and treated wastewater as fermentation substrate and the second $7.1 .10^{6} \mathrm{CFU} / \mathrm{mL}$ in the molasses-enriched soy yeast extract medium. This difference would probably be due to the amount of inoculum used for fermentation.

In conclusion he stands out of this study that the JMFC contains the necessary nutriments to support the growth and sporulation of Btk HD-1. Enrichment of this substrate with (2\% v/v) molasses improved the cellular and sporulation performance of Btk HD-1. The number of cells and spores obtained at the end of the 48 hours of fermentation was $1.6 \pm$ $0,026.10^{9} \mathrm{CFU} / \mathrm{mL}$ and $2.3 \pm 0,037.10^{9}$ $\mathrm{CFU} / \mathrm{mL}$ respectively. In view of these results, and until the efficacy of the fermented broths is evaluated on plant pests, the JMFC is a suitable substratum for the culture of this bacterium. Thus, the use of this juice for the production of Bacillus thuringiensis kurstaki var. HD-1 (Btk HD-1) represents a new alternative for the valorisation of this cocoa waste and can contribute to reduce the production costs of Btk HD-1-based biopesticide.

\section{References}

Adjallé, K.D., 2009. Etape ultrafiltration et procédé de formulation dans la production de biopesticides à base de Bacillus thuringiensis en utilisant des eaux usées et des boues d'épuration comme substrat. PhD, INRS-ETE, Université du Québec, Canada., 243 p.

Anvoh, K.Y.B. 2013. Valorisation du jus de mucilage de la fève fraiche de cacao (Theobroma cacao L.) et sa transformation en produits dérivés: Alcool, jus stabilise, marmelade, pâte à tartiner, vinaigre, Thèse de Doctorat, Université Nangui Abrogoua, 175p.

Barnabé,S., 2004.Hydrolyse et oxydation partielle des boues d'épuration comme substrat pour produire Bacillus thuringiensis HD-1. PhD, INRS-ETE, Université du Québec, Canada, 235 p.

Barje, F., El Fels L., El Hajjouji H., Amir S., Winterton P., Hafidi M., 2012. Molecular behaviour of humic acid-like substances during co-composting of olive mill waste and the organic part of municipal solid waste. International Biodeterioration and Biodegradation, 74: 17-23.

CEAEQ (Centre d'expertise en analyse environnementale du Québec), 2014. Détermination de l'azote total Kjeldahl et du phosphore total: digestion acideméthode colorimétrique automatisée. Ministère du Développement durable de l'Environnement et de la Lutte contre les changements climatiques, MA. 300 NTPT 2.0, Rév. 2, 16 p.

CEAEQ (Centre d'expertise en analyse environnementale du Québec et Ministère de l'agriculture, des pêcheries et de l'alimentation du Québec),2003. Détermination du $\mathrm{pH}$ à l'eau dans les sols agricoles, MA. 1010- $\mathrm{pH}$ 1.0, Ministère de l'Environnement du Québec, p.8.

El fels, L., Zamama M., El asli A., Hafidi M., 2014a.Assessment of biotransformation of organic matter during co-composting of sewage sludgelignocelullosic waste by chemical, FTIR analyses, and phytotoxicity tests. International Biodeterioration and Biodegradation, 87: 128-137.

Gadji, A.A.G., Yapo, O.B., ABO, K., Meité, L., Gnagne, A.E.Y., Brar, S.K., Tyagi, R.D. 2016. Utilisation du broyat de péricarpes des cabosses de cacao comme milieu de culture alternatif pour la production de Bacillus thuringiensisvar. kurstaki HD-1, Int. J. Biol. Chem. Sci. 10 (2): 632-641.

Gadji, A.A.G., 2017.Formulation d'un biopesticide à base de Bacillus 
thuringiensis var. kurstakiHD-1 et étude de son efficacité sur deux bioagresseurs du cacaoyer en Côte d'Ivoire: Phytophthorapalmivora et Sahlbergella singularis. Thèse de Doctorat, Université Nangui Abrogoua, Côte d'Ivoire, $215 \mathrm{p}$.

Gazali, A., Jaelani, A., Ilhamiyah, I., Erlina,S., 2019.Bacillus thuringiensis berliner cells population growth in some naturally media and the pathogenicity against Plutella xylostella Caterpilars, International Journal of Biosciences (IJB), Vol. 14, No. 2: 209-215

Martinez-Chois, C.J. 2012. Réhabilitation des sols pollués par les éléments traces métalliques grâce aux bactéries du sol associé à la rhizosphère de miscanthus $x$ giganteus. Thèse de Doctorat, Université de Lorraine, France, 167 p.

Mondédji, A.D., Nyamador, W.S., Amevoin, K., Adéoti, R., Abbey, G.A., Ketoh, G.K., Glitho, L.A., 2015. Analyse de quelques aspects du système de production légumière etperception des producteurs de l'utilisation d'extraits botaniques dans la gestion des insectes ravageurs des cultures maraichères au Sud du Togo. Int. J. Biol. Chem. Sci., 9 (1): 98-107.

Montiel, M.D.L.T., Tyagi, R.D., and Valero, J.R., 2001. Wastewater treatment sludge as a raw material for production of Bacillus thuringiensis based bioinsecticides. Wat. Res. 35: 38073816.

Mounsef, R.J., Salameh, D., kallassy, M.A., Brandam, C., Lteif, R., 2014. Evaluation of a cereal milling by-product for the low cost production of Bacillus thuringiensis kurstaki in submerged fermentation. European Journal of Biotechnology and Bioscience1 (6): 1016

Mourin, M., Shishir, A., Khan, S.N., Hoq, M.M., 2015. Regulation of major cultural components for designing a cost effective medium to increase deltaendotoxin synthesis by Bacillus thuringiensis. African Journal of biotechnology, 14(16): 1379-1386.

Ndao, A., Kumar, L.R.R., Tyagi, R.D., Valéro, J., 2019. Biopesticide and formulation processes based on starch industrial wastewater fortified with soybean medium, Journal of Environmental Science and Health, Part B, DOI: 10.1080/03601234.2019.1668225 13 p. Osman, G.E.H., Rasha, A., Assaeedi, A.S.A., Organji, S.R., El-Ghareed, D., Abulreesh, H.H., Althubiani, A.S., 2015. Bioinsecticide Bacillus thuringiensis a Comprehensive Review. Egyptian Journal of Biological Pest Control, 25(1): 271-288.

Salazar-Magallon J.A., HernandezVelazquez, V.M., Alvear-Garcia, A., Arenas-Sosa, I., Peña-Chora, G. 2015. Evaluation of industrial by-products for the production of Bacillus thuringiensis strain GP139 and the pathogenicity when applied to Bemisia tabaci nymphs, Bulletin of Insectology, 68 (1): 103-109, ISSN 1721-8861

Satinder, K., Verma, M., Tyagi R.D., Surampalli R., Barnabé S., Valéro J., 2007. Bacillus thuringiensis proteases: Production and role in growth, sporulation and synergism. Process Biochemistry, 42: 773-790.

Silverio, F., De Alvarenga, E., Moreno,S., et Picanco, M., 2009. Synthesis and insecticidal activity of new pyrethroids. Pest Manage. Sci., 65: 900-905.

Stephanie, T.M.M., Lourdes, A.G.R., María de Lourdes, M.R., Sergio, G.S., 2014. Effect of Carbon: Nitrogen Ratio on the Bacillus thuringiensis Spore Production. Journal of Chemical, Biological and Physical Sciences, 4(5): 50-56.

Toundou, O., 2016.Evaluation des 
caractéristiques chimiques et agronomiques de cinq composts de déchets et étude de leurs effets sur les propriétés chimiques du sol, la physiologie et le rendement du maïs (Zea mays L. Var. Ikenne) et de la tomate (Lycopersicum esculentum L. Var. Tropimech) sous deux régimes hydriques au Togo. Thèse de Doctorat, Université de Lomé, 213 p.

Valicente, F.H. and MourãoAndré, H.C., 2008. Use of By-Products Rich in Carbon and Nitrogen as a Nutrient Source to Produce Bacillus thuringiensis (Berliner)-Based Biopesticide. Neotropical Entomology 37(6):702-708. Valicente, F.H., Edmar de souza, T., MariaIsabella, S.L., Fernanda, L. F., Corina M.V., 2010. Production of bacillus thuringiensis biopesticide using commerciallab medium and agricultural by-products as nutrient sources. Revista Brasileira de Milho e Sorgo, 9, (1), p.111.

Vidyarthi, A.S., Tyagi, R.D., Valero, J.R., Surampalli, R.Y., 2002. Studies on the production of $B$. thuringiensis based biopesticides using wastewater sludge as a raw material. Water Research, New
York, 36: 4850-4860.

Vu K.D., Tyagi R.D., Valéro J.R., Surampalli R.Y., 2009. Impact of different $\mathrm{pH}$ control agents on biopesticidal activity of Bacillus thuringiensis during the fermentation of starch industry wastewater. Bioprocess Biosyst. Eng., 32: 511-519.

Yezza, A., Tyagi R.D., Valero, J.R., Surampalli, R.Y., 2005. Wastewater sludge pre-treatment for enhancing entomotoxicity produced by Bacillus thuringiensis var. kurstaki. World Journal of Microbiology \& Biotechnology, 21: 1165-1174.

Zhang, W., Lina, Q., Aijun, G., Yanqui, C., Wang, B., 2013. Solid-state fermentation of kitchen waste for production of bacillus thuringiensisbased biopesticide. Bioresource Technol. 8 (1): 1124-1135.

Zhuang, L., Zhou, S.G., Wang, Y.Q., Liu, Z., $\mathrm{Xu}, \quad$ R.X., 2011.Cost-effective production of bacillus thuringiensis biopesticides by solid-state fermentation using wastewater sluge: Effets of heavy metals. Bioresource Technol. 102 (7): 4820-4826.

\section{How to cite this article:}

ACHI Stanislas Maurice Akpo, YAPO Atse Alain, DJENI N' dede Théodore, GADJI Alahou André Gabaze, COULIBALY Kalpy Julien, GNEPE Jean Robert, YAPO Ossey Bernard and TYAGI Dayal Rajeshwar. 2020. Valorization of the Mucilage Juice of Cocoa Beans for the Production of a Biopesticide based on Bacillus thuringiensis var.kurstaki HD-1. Int.J.Curr.Microbiol.App.Sci. 9(11): 3600-3610. doi: https://doi.org/10.20546/ijcmas.2020.911.431 